\title{
COVID-19 Vaccination Services: Legal Issues and Protection for Health Workers
}

\author{
Irzal Rakhmadhani ${ }^{1}$, Erna Yulida ${ }^{2}$, Fahrina ${ }^{3}$ Abdul Kadir Jaelani ${ }^{4}$ \\ ${ }^{1,2,3}$ District Health Office of Hulu Sungai Utara, South Kalimantan, Indonesia \\ ${ }^{4}$ Universitas Sebelas Maret, Surakarta, Indonesia \\ irzal.rakhmadhani@gmail.com
}

\begin{abstract}
COVID-19 cases are on the rise, and strict health protocols haven't been able to keep up. COVID-19 vaccinations are required to slow the transmission of the virus in the community; lessen pain and death caused by the disease; accelerate herd immunity, and protect the community from COVID-19 during the recovery of social and economic activities. However, COVID-19 vaccination is still experiencing various obstacles due to public rejection of vaccination which leads to potential legal problems between health workers and certain community groups. The purpose of this article is to investigate potential legal issues as well as the protection of health workers involved in the COVID-19 vaccination service at Health Service Facilities. The method that is used in this scientific journal is normative juridical. The public's refusal of COVID-19 vaccination raises various problems, and they lead to public misunderstandings including accusations of vaccination conspiracy by health workers. According to a review of the literature, health workers in COVID-19 vaccination in Indonesia are legally protected if the services are provided in accordance with established procedures. RI Law No. 29 of 2004 concerning Medical Practice, Presidential Regulation No. 14 of 2021, Regulation of the Health Minister of Republic Indonesia No. 269 and 290, and Decree of the Minister for Public Health HK.01.07/Menkes/413/2020 concerning Guidelines for Prevention and Control Coronavirus Disease 2019 all contain aspects of legal protection for health workers.
\end{abstract}

Keywords-Legal Problems, Legal Protection, Health Workers, COVID-19 Vaccination.

\section{INTRODUCTION}

The pandemic of Coronavirus disease in Indonesia has had a wide-ranging impact on health, social, and economic aspects. Because of the threat posed by the virus's new variant, the increase in new daily cases in the Second Wave of COVID-19 is more dangerous. The early variant of coronavirus (wild type) itself naturally had a low mutation rate. However, high transmission of SARS-CoV-2 in the community allows the emergent variants of concern (VOC) mutations that are more contagious with a higher ability to avoid the immune system and therapeutic modalities. There are four main VOC variants found in Indonesia, namely the SARS-CoV-2 alpha, beta, gamma, and delta variants [1].

The threat of SARS-CoV-2 VOC is getting bigger due to the lack of public awareness in implementing health protocols (wearing masks, washing hands, maintaining physical distancing, avoiding crowds, and reducing mobility). COVID-19 is expected to cause 2.5 million illnesses and 250,000 deaths without immediate and proper public health response. To break the cycle of SARS-CoV2 transmission, rigorous health standards must be implemented, along with a rapid increase of COVID-19 vaccination. To limit COVID-19 transmission, illness, and mortality owing to COVID-19 as well as achieve herd immunity, as well as preserve the community so that it can stay socially and economically productive [2].

Indonesia has begun vaccinating against COVID-19 since January 2021, with the Ministry of Health setting targets. Public servants, health workers, youth, pregnant women, and other susceptible populations have all received the COVID-19 vaccine. Along with the research, the COVID-19 vaccine in Indonesia has undergone various revisions and improvements.

However, three main problems hinder the acceleration of the COVID-19 vaccination program: incompatibility of vaccines supply and vaccinator team's ability with the number of vaccination targets; uneven vaccines' distribution has resulted in a shortage of COVID-19 vaccines outside Java-Bali areas; public refusal to participate in COVID-19 vaccination in some regions. These three main problems have resulted in low vaccination coverage in Indonesia. On August 15th 2021, number of first dose recipients of COVID-19 vaccination was $53,688,122$ residents of $208,265,720$ population $(25.78 \%)$ [3].

Public refusal of the COVID-19 vaccine creates potential legal problems for health workers related to the COVID-19 vaccination. It is because the refusal to comply with national vaccination obligations and the threat of administrative sanctions may result in a bad public perception of health workers. This paper will identify potential legal problems in COVID-19 vaccination and describe legal protection efforts from Government through various legal products as long as health workers carry out vaccination services according to established procedures[4].

\section{RESEARCH METHOD}

A normative juridical method was adopted in this study. This involved gathering library resources and secondary legal materials by doing searches on relevant rules and 
publications. The legal and conceptual approach has been applied to develop the project. The current legal materials are then qualitatively reviewed in order to come up with a solution to the issues studied.

\section{FINDINGS AND DISCUSSION}

The current COVID-19 vaccination in Indonesia has been running for eight months. The COVID-19 vaccination program is divided into four stages, depending on the vaccine's availability, arrival time, and safety profile. The priority group for vaccine recipients is the Indonesian population aged 18 years. There are now no restrictions on the vaccination of children under the age of 18 due to the availability of acceptable vaccine safety data, an emergency use authorization from Food and Drug Supervisory Agency, and a distribution permit number. The National Immunization Expert Advisory Committee (ITAGI) also recommends the safety of the Sinovac (Coronavac), Moderna, and Pfizer COVID-19 vaccinations for pregnant women in its recommendations. In order to avoid disinformation and uncertainties regarding vaccine safety, increasing the number of targets involves public education and outreach.

Mass vaccination services in health care facilities cause a variety of potential problems. Problems that often occur are:

\section{Visitors and health workers are exposed during vaccination.}

The public needs to know that health services in health facilities that implement health protocols are very safe [5]. However, it will decrease if these health protocols are not carried out properly by health workers and health service visitors. The Ministry of Public Health mandates that COVID-19 vaccination services must not interfere with basic health service activities, such as routine immunization services, basic medical services, maternal health services, and other types of health services [2]. This allows the COVID-19 virus to spread through the crowd. This situation greatly increases the risk of being infected by SARS CoV-2, especially in primary health facilities with small open spaces to carry out vaccination but must provide vaccination services to the targets.

Massive COVID-19 vaccinations in the public areas pose a challenge to health workers and the sectors involved. There is an increased risk of exposure to COVID-19 due to a large number of vaccination targets, a lack of awareness in the implementation of health protocols during the vaccination process, and an imbalance between the number of health workers who provide services and the number of vaccination participants.

It can also occur due to misinformation that after being vaccinated, the targets are fully protected; so that, health protocols are not implemented properly. It is important to understand that vaccine effectively reduces morbidity and mortality due to COVID-19 after 28 days of second dose vaccine administered. Therefore, the implementation of health protocols is still needed. Another problem is those who are infected by COVID-19 still get vaccinated and are only discovered sometime later. As the result, they assume that COVID-19 vaccination is ineffective and because of the vaccine, they are infected. This can occur under 2 conditions: unopened targets that had symptoms of COVID-19 or were recently contacted with the confirmed case; and targets with asymptomatic cases so that they are not detected during pre-vaccination screening.

\section{The process of vaccination services is constantly evolving}

The procedure for the COVID-19 vaccination services continues to change by the development of science to achieve the effectiveness of vaccination. One of the most important changes that occur most frequently is the question of screening for the eligibility of vaccination targets. Initially, the technical guidelines for vaccination set out 16 conditions and diseases that were contraindicated for COVID-19 vaccination. Based on evidence-based data and the latest clinical trials, technical guidelines currently only include 6 contraindications for COVID-19 vaccination with additional targets for adolescents, pregnant and breastfeeding women, and targeted elderly and COVID-19 survivors who had not previously received COVID-19 vaccination [2]. This change has the potential to cause misunderstandings for some people because they do not meet the criteria for vaccine recipients according to initial technical guidelines.

Vaccination procedures will continue to change in line with the development of vaccine research and the types of vaccines provided by the government. The government needs to regulate this development by issuing relevant and applicable regulations for health workers. Health workers also need to learn the latest information related to vaccinations to provide safe vaccination services.

\section{Occurrence of Adverse Event of Following Immunization (AEFI) in vaccine recipients}

Adverse Events of Following Immunization (AEFI) are medical events that are thought to be related to vaccination. This medical event can be a reaction after vaccination, error in injection procedure, incident (another medical condition that occurs simultaneously), anxiety reaction of the vaccine recipient, or undetermined causal relationship. This adverse event considers serious if hospitalization is needed, persistent sequel, life-threatening medical conditions, and death. This event can occur in all types of vaccination because of the condition differences of each vaccine recipient [2]. The issue is raised by the anti-vaccine community against the COVID-19 vaccine to widespread public rejection of vaccination. 
The Anti-vaccine community propagate their ideas in the form of the COVID-19 vaccine is unsafe and is required solely for reasons of economic gain from both the sale of the vaccine and the treatment of vaccinated recipients with AESI; The COVID-19 vaccine is not effective in preventing COVID-19 in the community; The COVID-19 pandemic is not as severe as the official state media reports so that the mandatory COVID-19 vaccination is not necessary and violates human rights [6].

In general, Indonesia has made legal protection for health workers in carrying out their duties according to established standards. In addition, the government has also issued guidelines and technical instructions for the implementation of vaccination as a standard for implementing it in the field [7].

\section{Medical Practice Law No. 29 of 2004}

Patients, doctors, and dentists will be protected and have legal certainty within this law. The goal of medical practice settings is to protect patients, sustain and improve the quality of medical services performed by doctors and dentists, and provide legal certainty to the public, doctors, and dental professionals.

Legal protection is provided to doctors who do their tasks in accordance with the approved protocols. In the context of this epidemic and a variety of problems with the local community, health personnel may face legal issues [8]. This Law provides legal protection and provides basic legal and reorganizes various legal instruments that regulate the implementation of medical practice. This law regulates principles and objectives of medical practice, the establishment of the Indonesian Medical Council, medical professional education standards, education and training in medicine and dentistry, registration of doctors and dentists, the implementation of medical practice, the establishment of Indonesian Doctors Discipline Honorary Council, as well as guidance and supervision on medical practice [9]. In carrying out their profession, doctors and dentists can also be punished according to provisions stipulated in this Law. However, in carrying out disaster management, doctors do not need Medical License as a physician practicing but are required to have Provisional Registration. Legal protection is needed so that they can provide health services comprehensively [10].

\section{Law No. 36 of 2014 on Health Workers}

In addition to providing the best quality of health services, health workers play a key role in helping the community become more conscious, willing, and able to live a healthy life. This shall be achieved by investing in developing socially and economically effective human resources as well as public welfare, as stated in the Preamble to the Republic of Indonesia Constitution of 1945.

Medical professionals are required to meet community needs, and the community must be protected when accepting health services. In addition, the law intends to improve the quality of health care delivered by Health Workers and offer legal certainty to the public and health workers.

People who work in the health sector have acquired knowledge and skills through education and are already registered to provide health services. COVID-19 is more likely to infect health personnel who provide care to COVID-19 patients [11]. If they perform their tasks in accordance with established standard procedures, health workers deserve to be protected by law. Human dignity, morals, decency, and religious values protect health care professionals' workplace safety and health [12]. During the COVID-19 pandemic, health workers are the primary resources for the handling of this pandemic. Therefore, the Government must provide protection and guarantee their rights in providing health services.

3. In the context of Coronavirus Disease 2019, Presidential Regulation No. 14 from 2021 amends Presidential Regulation No. 99 from 2020 governing procurement and implementation of vaccines (COVID19) Pandemic

In order to combat the COVID-19 outbreak/pandemic and protect public health, it is essential to prioritize and secure the supply of COVID-19 vaccines as soon as possible. Also, the implementation of the COVID-19 Vaccination must take place in accordance with the government's requirements and available resources. That same legislation also applies to COVID-19 Vaccinations, the procurement of which is subject to extraordinary steps and specific arrangements.

Through the acquisition of vaccines and execution of COVID-19 vaccinations, this Presidential Regulation aims to accelerate COVID-19 prevention. Purchase and implementation of vaccinations involve the purchase of vaccines, vaccination implementation, and funding for vaccine procurement supported by ministries, institutions, and local authorities. The community's COVID-19 vaccination program is governed by Article $13 \mathrm{~A}$. The COVID-19 vaccination must be administered to everyone who meets the criteria. Whoever refuses to take part in the COVID-19 Vaccination program could face the administrative penalty, including delaying or ceasing the provision of Social Security or Social Assistance, delaying or ceasing the provision of Government Administration Services, or paying fines [13].

After receiving the COVID-19 vaccine, it's important to keep track of and report on what's going on. Medical facilities or health offices record, report, and investigate adverse events, with field etiology conducted by the Regional Committee for the Assessment and Management of Special Interest Adverse Events, and causality studies by the National Committee for Special Interest Adverse Event Assessment and Management. Article 15 also guarantees 
that every AEFI case receives treatment under medical indications and treatment protocols [13].

\section{Guidelines for Prevention and Control of Coronavirus Disease 2019 - Minister of Public Health Regulation HK.01.07/Menkes/413/2020}

Public Health Ministry continues changing the guidelines in preventing and controlling COVID-19 pandemic based on the latest research results. This guideline is used as a reference for health workers and health facilities in carrying out services to overcome the pandemic [14]. The latest guidelines on prevention and control of COVID-19 (revision V) are the basis for handling this disease in all health facilities. Each revision contains changes in several substances according to the knowledge and development of the situation. As well as directions for COVID-19 diagnosis based on the results of the SARS COV-2 fast antigen test or PCR swab [15], this guideline includes a reference for surveillance and tracking suspected patients and close contacts. To diagnose COVID-19-infected targets and defer immunization for up to three months after the target recovers, vaccine screening officials should use these instructions.

Over time, the Ministry of Health revises the document, resulting in Decree HK.01.07/Menkes/5671/2021 of the Minister of Health Republic of Indonesia Concerning Clinical Management Procedures Corona Virus Disease 2019 (COVID-19) in Health Care Facilities. Health care facilities can refer to this rule when treating the confirmed patients.

5. Prevention and Control Division, Directorate General Regarding the Coronavirus Disease Prevention and Control Guidelines for 2021, see HK.02.02/4/1/2021.

This regulation is used as a reference for the implementation of COVID-19 vaccination for the Government (Central, Provincial, and Regency/City) as well as health facilities that provide COVID-19 vaccination services. These technical guidelines cover vaccines supply planning, target recipients, funding for vaccination, distribution, and other vaccine management. It also regulates recording and reporting, monitoring and preventing AEFIs [2].

Technical guidelines underwent several changes and adjustments in the form of:

a. Changes to COVID-19 vaccine screening through circular letter HK.02.02/I/368/2021 concerning the application of COVID-19 vaccinations for the Elderly, Comorbid and COVID-19 Survivor Target Groups, as well as Delayed Targets.

b. Simplification of vaccination services through the circular letter of Directorate General of Prevention and Control Disease SR.02.06/II/1123/2021 on April 30th, 2021 concerning simplification of COVID-19 Vaccination Service Flow. This simplification includes simplification of procedures for registration of prospective vaccine recipients, simplification of vaccination flows, and changing some screening questions.

c. Children and pregnant women's COVID-19 vaccinations are addressed in circular HK.02.01/1/2007/2021 on COVID-19 Vaccination for Pregnant Women and Screening Adjustments for Implementing COVID-19 Vaccination.

As part of the COVID-19 immunization program in Indonesia, BPJS Kesehatan uses the "Pcare Vaccination" application, which is controlled and updated in accordance with existing norms and procedures. With the implementation of the Pcare application, the COVID-19 vaccination services in Indonesia are projected to be improved. While administering vaccinations to patients, health workers now use the BPJS Vaccination P-Care application to track vaccination activities and report their findings. In addition, this application is linked to the "Peduli Lindungi" application to provide community members with information on COVID-19.

The five legal products above are the main regulations that provide legal protection for health workers. Whether for health workers during the pandemic in general or vaccination health workers in particular. Statute regulations in points 1 and 2 regulate legal protection for health workers, especially in normal circumstances or in disaster/pandemic conditions. Points 3, 4, and 5 of the regulations involve guidelines for the implementation of health services during a pandemic, both in the form of services to prevent and handle COVID-19, as well as accelerate the implementation of COVID-19 vaccine in the community. As a result of administrative responsibilities and punishments, herd immunity against this outbreak is expected to be enforced. However, the public does not need to feel compelled and worried about vaccination services because the relevance of technical instructions has guaranteed the efficiency of the vaccine, vaccination services delivered by trained health workers, and the targets have guaranteed eligibility before being vaccinated. It has to be shared with the public so that the community and health workers realize that they are legally protected by the law.

Health workers in Indonesia have a huge challenge in handling COVID-19. In addition to being involved in COVID-19 vaccination, health workers also play a major role in handling COVID-19 through 3T (Testing, Tracing, and Treatment). 3T efforts or Tests, identifying contacts (trace), and treatment of COVID-19 patients are some of the most important COVID-19 management initiatives.

During a pandemic, the protection of health care personnel should be a top priority for the government. Overall, COVID vaccination-19 service and handling protection should be given substantial consideration under the law. The COVID-19 pandemic is not ended yet, and the government must be mindful of the dynamic advances in handling COVID-19. Updated regulation is needed to make it relevant based on the latest scientific research. The 
government has to be ready in providing legal protection for the community and health workers and ensuring optimal regulation to overcome this pandemic.

\section{IV.CONCLUSION}

COVID-19 pandemic in Indonesia has changed various aspects of life. Implementation of strict health protocols is not enough to end the pandemic so that COVID-19 vaccination is expected to significantly reduce morbidity and mortality in the community. Accelerating COVID-19 Vaccination has become the government's focus in handling COVID-19. However, there are many problems in implementing vaccination that may have potentials legal problems for health workers who provide vaccination services. According to the basic rule of law in Indonesia, health personnel who carry out vaccinations are protected from lawsuits if they follow established procedures. To ensure that health care employees are protected in the course of their tasks. Determining the public's trust in vaccination is also crucial, so that herd immunity can be obtained rapidly.

\section{REFERENCES}

[1] Hartono and Y. Yusuf, "Tinjauan Molekuler Dan Epidemiologi Mutasi Pada virus SARS-COV-2," bionature, vol. 22, no. 1, pp. 43-49, 2021.

[2] Dirjen P2. Keputusan Direktur Jenderal Pencegahan dan Pengendalian Penyakit Nomor Hk.02.02/4/1/2021 Tentang Petunjuk Teknis Pelaksanaan Vaksinasi Dalam Rangka Penanggulangan Pandemi Corona Virus Disease 2019 (COVID-19). Jakarta: Kemenkes RI. 2021

[3] "Vaksinasi COVID-19 Nasional: Data Per Tanggal 15 Agustus 2021 Pukul 18.00 WIB," Vaksin Dashboard, 14-Aug-2021. [Online]. Available: https://vaksin.kemkes.go.id/\#/vaccines. [Accessed: 15-Aug-2021].

[4] T. L. Pesulima and Y. Hetharie, "Perlindungan Hukum terhadap keselamatan Kerja Bagi Tenaga Kesehatan akibat pandemi COVID-19," SASI, vol. 26, no. 2, pp. 280-285, Apr. 2020.

[5] A. Richterman, E. A. Meyerowitz, and M. Cevik, "Hospital-acquired SARS-COV-2 infection," JAMA, vol. 324, no. 21, pp. 2155-2156, Dec. 2020.

[6] M. S. Hakim, "SARS-COV-2, COVID-19, and the debunking of conspiracy theories," Reviews in Medical Virology, Feb. 2021.

[7] D. Trihandini, "Konsep Perlindungan Hukum Bagi Tenaga Medis Dalam Penanganan COVID-19," Jurnal Hukum dan Pembangunan Ekonomi, vol. 9, no. 1, pp. 52-64, 2021.

[8] Sjamsuhidajat R, Meilia PDI, Zulfiyah IA. Etika Kedokteran dalam Kegiatan Tanggap Darurat Bencana. JEKI. 2020; 4 (1): 1-8. doi: 10.26880/jeki.v4i1.39.

[9] Undang-Undang tentang Praktik Kedokteran 2004 (UU) 29 (Ind.).

[10] H. Fajar, "Perlindungan Hukum Terhadap Dokter yang Telah Melaksanakan Tugasnya Sesuai Dengan
Prosedur Menurut Undang-Undang Nomor 29 Tahun 2004 Tentang Praktik Kedokteran," JOL, vol. 1, no. 2, pp. 1-15, 2019.

[11]T. Aktariyani, Darwito, Rimawati, and L. Trisnantoro, "Perlindungan Hukum Residen dalam Penanganan Pasien COVID-19 di Indonesi," JKKI, vol. 9 , no. 4, pp. 225-231.

[12] Undang-Undang tentang Tenaga Kesehatan 2014 (UU) 36 (Ind.).

[13] Peraturan Presiden (PERPRES) tentang Perubahan atas Peraturan Presiden Nomor 99 Tahun 2020 tentang Pengadaan Vaksin dan Pelaksanaan Vaksinasi Dalam Rangka Penanggulangan Pandemi Corona Virus Disease 2019 (Covid-19) 2021 (Perpres) 14 (Ind.).

[14]Keputusan Menteri Kesehatan tentang Pedoman Pencegahan dan Pengendalian Corona Virus Disease 2019 (COVID-19) $2020 \quad$ (Kepmenkes) HK.01.07/MENKES/413/2020 (Ind.).

[15] Kementerian Kesehatan RI. (2020). Pedoman Pencegahan dan Pengendalian Corona Virus Disease (Covid-19) Revisi 